\title{
Effect of the Addition of Hydrocolloids to Tomato-Carrot Juice Blend
}

\author{
Onyinyechi Gift Nwaokoro* and Charles Taiwo Akanbi \\ Department of Food Science and Technology, Obafemi Awolowo University, Ile-Ife, Osun state, Nigeria
}

Received: July 10, 2014; Accepted: December 20, 2014; Published: January 05, 2015

*Corresponding author: Onyinyechi Gift Nwaokoro, Department of Food Science and Technology, Obafemi Awolowo University, Ile-Ife, Osun state, Nigeria, Tel: 806-565-8853; E-mail: nogtoexcel@yahoo.com

\begin{abstract}
The study determined the effect of addition of hydrocolloids to tomato-carrot juice blend. It also determined some physico-chemical parameters and evaluated the proximate and microbial analyses of the blend. This was with a view to provide information on the properties of tomato-carrot juice blend which gives the most acceptable quality. Two samples of tomato-carrot juice blend were prepared, with one containing hydrocolloids while the other was without hydrocolloids. The products were bottled, pasteurized, cooled and stored at ambient $\left(29 \pm 1^{\circ} \mathrm{C}\right)$ and refrigeration $\left(5 \pm 1^{\circ} \mathrm{C}\right)$ temperatures. There was a significant difference in some of the physico-chemical properties $(\mathrm{t}$ $=2.93, p<0.05)$ and sensory evaluation $(\mathrm{t}=3.20, p<0.05)$ was done between the blend with and without hydrocolloid. The blend with hydrocolloids had better retention of juice quality parameters.
\end{abstract}

Keywords: Tomato-carrot juice; Hydrocolloids

\section{Introduction}

Juice is classified as puree, if the resulting consistency is fluid that pours very slowly or pulp if it pours even more slowly. The addition of sugars or acids can be permitted but must be endorsed in the individual standard [1].

According to the Office of Dietary Supplement [2], blending of juices helps in balancing out juices with weak or bland flavour, excessively strong flavours, primarily high acidity, astringency or bitterness, correcting low soluble solids level, improving poor colour or colour stability of otherwise desirable juices attributes, emphasizing unique nutritional and phytochemical properties and overcoming undesirable single strength juice consistency.

Tomatoes are the fruits of the plant Lycopersicon lycopersicum and are one of the most widely grown tropical vegetable. Tomato is known and grown world-wide and is processed to give various products [3]. In Nigeria, tomatoes are grown in large quantities and are seasonal. Tomato juice is an important product and the quality (taste) of juice is mostly judged by its combination of sourness (titratable acidity) and sweetness (total soluble solids) [4]. Daily consumption of tomato products provides at least 40 mg of lycopene, is enough to substantially reduce Low Density Lipids (LDL) oxidation. This lycopene level can be achieved by drinking just two glasses of tomato juice a day [5].
Carrot is an important root crop cultivated throughout the world for its fleshy edible roots; and is used for human consumption as well as animal feed. Carrots are rich source of beta- carotene (and contain appreciable amounts of thiamine and riboflavin [6]. Carotenoids in carrot and tomato have also been linked with enhancement of the immune system and decreased risk of degenerative diseases such as cancer, cardiovascular disease, age-related macular degeneration, and cataract formation [7]. Carrot has long been a component of tomato blends. Sedimentation is a main problem in carrot juice. Several studies reported that cloud stability could be improved by using polysaccharides stabilizer and reducing pulp content, however this might affect texture attributes of the product [8].

Hydrocolloids are substances that form gels in contact with water. Such substances include both polysaccharides and proteins which are capable of one or more of the following: thickening and gelling aqueous solutions, stabilizing foams, emulsions and dispersions and preventing crystallization of saturated water or sugar solutions [9]. Examples of hydrocolloids are carboxymethylcellulose, guar gum, starch, xanthan gum, pectin, gelatine among others [10]. Carboxymethylcellulose (CMC) is a modified cellulose gum (cellulose is a component of plant fibre). In foods, it is used as a stabilizer, thickener, film former, suspending agent and extender. The allowable percentage range is 0.05 to $0.5 \%$ of the total product [11]. Xanthan gum is an extracellular polysaccharide secreted by Xanthomonas campestris. At low shear rates, solutions of xanthan gum have approximately 15 times the viscosity of guar gum and significantly more viscous than carboxymethylcellulose (CMC) or sodium alginate which accounts for its superior performance in stabilising suspensions [12]. In order to adjust the desired flow behaviour, Xanthan Gum is used in combination with other hydrocolloids [13]. Typically, Xanthan Gum is used at $0.1-0.2 \%$ concentration [14]. Concentrations of Xanthan Gum (XG) and Carboxymethylcellulose (CMC) of $0.4-0.5 \%$ completely inhibit apple juice clarification. At lower gum concentrations, juices with CMC were more stable. At low shear rates, $\mathrm{XG}$ was more viscous than CMC, demonstrating that the greater stabilizing effect of CMC was basically due to its electro-negativity [15]. Alakali et al. [16] reported that the use of CMC at levels $0.5,0.75$ and 
$1.0 \%$ depressed the production of lactic acid (titratable acidity), increased the viscosity and showed significant differences $(p>$ 0.05 ) in the ash content of thermized yogurt. The addition of guar gum had a greater effect on the increase of viscosity than CMC and xanthan gum supplementation. Xanthan gum also caused a significant $(p<0.05)$ increase in the apparent viscosity of the tomato ketchup [17]. Therefore, the present investigation was aimed at studying the effect of hydrocolloids on the physicochemical, some proximate, microbial and sensory properties of tomato-carrot juice blend.

\section{Materials and Methods}

\section{Materials}

Ripe and fresh tomato fruits (Lycopersicon lycopersicum) and fresh carrots (Daucus carota L) were purchased from the local market in Ile-Ife, Osun-state. The hydrocolloids (carboxylmethylcellulose, xanthan gum and guar gum), sodium benzoate, citric acid, aspartame and other chemicals were of analytical grade obtained from Captain Investment Limited, Surulere, Lagos. The equipment and bottles used for packaging in this study were obtained from the Department of Food Science and Technology, Obafemi Awolowo University, Ile-Ife, Osun State.

\section{Methods}

The fresh tomatoes were washed with portable water and sorted (blemished fruits were discarded). The carrot roots were washed thoroughly; both ends were removed and peeled with a sharp stainless steel knife. The sorted fruits and the cleaned carrot roots were separately blanched in hot water $\left(90^{\circ} \mathrm{C}\right.$ for 3 min) and the juice were extracted using a Juice extractor (JM300, Salton R, Juiceman, UK). The juice of each fruit was filtered using muslin cloth. Hydrocolloids (carboxyl methylcellulose and xanthan gum), aspartame and preservatives (sodium benzoate and citric acid) were dissolved in $50 \mathrm{ml}$ of water using a mixer (YT518WB, Gazab, Kachan, Hong Kong). Tomato-carrot juice (scale-up to $250 \mathrm{ml}: 160 \mathrm{ml}$ tomato juice and $90 \mathrm{ml}$ carrot juice) and $50 \mathrm{ml}$ of the dissolved solution containing hydrocolloids, aspartame and preservatives were filled into the glass bottles, corked and pasteurized at $85^{\circ} \mathrm{C}$ for 15 minutes. The pasteurized juice was allowed to cool and stored at ambient temperature (29 $\left.\pm 1^{\circ} \mathrm{C}\right)$ and refrigeration temperature $\left(51^{\circ} \mathrm{C}\right)$ for 8 weeks.

\section{Determination of Physico-chemical parameters:}

pH and total titratable acidity: The $\mathrm{pH}$ of the samples was determined by using a $\mathrm{pH}$ meter with a glass electrode (Model H198130, Combo PH/EC/TDS, Hanna Instruments, Italy). Buffer 4.0 and 7.0 were used to standardize the electrode and it was cleaned and dipped into samples after stirring with a glass rod. Readings were taken in triplicates and mean values were calculated and recorded.The total titratable acidity was determined according to AOAC method [18]. Ten millilitres of each sample at ambient and refrigeration temperatures were pipetted into a conical flask and three drops of phenolphthalein indicator was added. The mixture was titrated against $0.1 \mathrm{M} \mathrm{NaOH}$ solution in burette while swirling gently. A permanent faint pink colour was recorded as end point the mean values were used in calculating the titratable acidity expressed as percentage of citric acid using the formula;

$$
\% \text { citric acid }=\frac{T \times 192}{3 \times 1000}
$$

where: $\mathrm{T}=$ mean titre $(\mathrm{in} \mathrm{ml})$ of $0.1 \mathrm{M}$ solution of sodium hydroxide required to neutralize the acidity in $10.0 \mathrm{ml}$ of the juice (192 is the molecular weight (relative molecular mass) of citric acid).

Degree brix ( ${ }^{\circ}$ Brix): Degree brix ( ${ }^{\circ}$ Brix) was determined using Hand Refractometer (M 300002, Super Scientific, USA). The sample was placed on the prism of refractometer then the daylight plate was closed, and the scale where the boundary line intercepts was read. The percentage scale of the refractometer was shown in 100 grams of aqueous solution and was equal to Brix number ( ${ }^{\circ}$ Brix). All measurements were performed in triplicates and mean values were obtained.

Total ascorbic acid (a.a): Ascorbic acid was estimated using the method of AOAC [18]. Blank was prepared by titrating $0.2 \mathrm{ml}$ of standardized 2,6-dichlorophenol indophenol (dye) against 7.0 $\mathrm{ml}$ of extracting solution (oxalic acid) while standard ascorbic value was obtained by titrating dye against a mixture of $2 \mathrm{ml}$ of blank a. a solution and $5 \mathrm{ml}$ extracting solution. About $20 \mathrm{ml}$ of tomato-carrot juice blend was made up to $50 \mathrm{ml}$ with oxalic acid, the diluent was filtered and $5 \mathrm{ml}$ of the extract was pipetted into a beaker and titrated with the dye. The coloured solution changed to pink to mark the end point. All analysis was carried out in triplicates.

Total reducing sugar content: The modified dinitrosalicylic acid method was used to determine the total reducing sugar of the samples [19].

Carotenoids and lycopene contents determination: About $0.6 \mathrm{~g} \pm 0.01 \mathrm{~g}$ duplicate samples were weighed from each juice blend into conical flask wrapped with aluminium foil to exclude light. A $30 \mathrm{ml}$ mixture of hexane-acetone-ethanol (2:1:1) was added to solubilize all lycopene (acetone contained $0.05 \%$ BHT). The flask was stoppered and agitated for $15 \mathrm{~min}$ on a magnetic stirrer to extract lycopene. This was confirmed when the solution became colourless. Five $\mathrm{ml}$ of distilled water was added to the mixture and sample was stirred for 5 minutes to separate the solution into polar and non-polar layers [20]. The solution was transferred into a separating funnel to separate into distinct polar $(20 \mathrm{ml})$ and a non- polar $(10 \mathrm{ml})$ layer containing the lycopene was filtered [21]. Absorbance of the upper layer was read at $502 \mathrm{~nm}$ for lycopene and $450 \mathrm{~nm}$ for carotenoids blanked with hexane using a UV-VIS Spectrophotometer (UNICAM UV/UV/ US/SPECT UVI 061408). Estimation of lycopene was based on extinction coefficient (3450) at $502 \mathrm{~nm}$ in hexane and carotenoid estimate is based on extinction coefficient (2500) at $450 \mathrm{~nm}$ in hexane [20]. Analysis was carried out in triplicates.

Lycopene and Carotenoid concentration were calculated as given by Davies [22] in mg/100g:

$$
\text { Lycopene concentration }=\frac{\mathrm{A} \times 10^{4}}{\text { Weight } \times 3450}
$$




$$
\text { Carotenoid concentration }=\frac{\mathrm{A} \times 10^{4}}{\text { Weight } \times 2500}
$$

where $\mathrm{A}=$ absorbance.

Moisture content: The moisture content was determined according to AOAC [18].Two millilitres of each sample was measured into a weighed porcelain crucible and dried for 5 hours at $105^{\circ} \mathrm{C}$ to a constant weight. Calculation of moisture content was as follows:

$$
\% \text { Moisture content }=\frac{\text { Original weight }- \text { Final Weight }}{\text { Original weight }} \times 100
$$

Ash content: According to AOAC [18] method, ash content was determined by measuring $2 \mathrm{ml}$ of samples into tared porcelain crucibles and placed in an oven for 3 hours operated at $100^{\circ} \mathrm{C}$ to evaporate all moisture. The crucible and its content are then transferred into a furnace at $550^{\circ} \mathrm{C}$ for 2 hours. The furnace was switched off and allowed to cool. The crucible plus ash was weighed. The ash content of the samples was calculated as follows;

$$
\% \text { Ash content }=\frac{\text { Final weight of Ash }}{\text { Original weight of sample }} \times 100
$$

Total solids content: AOAC [18] method was used to determine the total solids content of the respective samples. Two millilitres of each sample was measured into a previously weighed flat bottom dish and samples were heated on a steam bath for 15 minutes. The samples were transferred to a hot air oven and heated for 3 hours at $100^{\circ} \mathrm{C}$. They were cooled in desiccators and weighed. The percentage residue was calculated and recorded as total solids.

Conductivity and level of sedimentation: The conductivity of the juice was measured using a conductivity meter (HI 8733, Hanna Instrument, Italy). The sediment at the bottom tube of the tomato-carrot juice blend was examined by observation of the physical appearance. Sediment was observed in both samples stored at ambient and refrigeration temperatures. Sedimentation level of each juice sample was calculated as follows and expressed in percentage:

$$
\frac{\text { Level of Sedimentation }}{\text { Volume of juice }} \times 100 \%
$$

Viscosity: The viscosity of each sample was determined at room temperature by using a Brookfield digital viscometer (NDJ85, Noryn Intelligent Company limited, Shanghai). A suitable spindle (spindle 2) and rotational speed (60 rpm) was selected for this study. The spindle attached to the instrument with a vertical shaft was rotated in the fluid. This device gives the viscosity of Newtonian fluids directly $(\mathrm{mPa})$ since it is calibrated with Newtonian oil [23].

Colour determination: The Munsell colour system was used to determine the colour of each sample calculations on the notations from a sample's X, Y and Z Tristimulus values using the Disk Spinning Method. The hue and chroma values were obtained from the chart as described by the Munsell Colour Company (1969). Munsell colour notations are written in the same sequence as hue, value/ chroma.

Microbiological analysis: The microbial analysis carried out on each sample stored at ambient and refrigeration temperatures were Total Plate Count (TPC) and total Yeast and Mould Count (YMC). The media used (Nutrient agar and Potato Dextrose agar respectively) were prepared according to manufacturer's instruction. The media and test tubes containing the $9 \mathrm{ml}$ of distilled water were sterilized by autoclaving at $121^{\circ} \mathrm{C}$ for 15 minutes. A sterile pipette was used to aseptically add $1 \mathrm{ml}$ of sample to a labelled test tube containing $9 \mathrm{ml}$ of sterilized distilled water. Further serial dilutions $\left(10^{-1}\right.$ to $\left.10^{-4}\right)$ were made with fresh sterile pipette for each dilution as described by Ogbulie et al. [24]. Fresh sterile pipettes were then used to aseptically transfer $1 \mathrm{ml}$ of each sample dilution from the test tubes into corresponding labelled duplicate petri dishes.

Pour plating: Molten agar medium (Nutrient agar for bacteria, Potato dextrose agar for yeast and mould) were cooled to $45^{\circ} \mathrm{C}$ and aseptically poured over the samples in the petri dishes, swirled gently to mix and the plates were allowed to solidify. The plates were then inverted and incubated. Nutrient agar used for bacterial isolation was incubated at $37^{\circ} \mathrm{C}$ for $24-$ 48 hours while potato dextrose agar used for yeast and mold isolation was incubated at $37^{\circ} \mathrm{C}$ for $48-72$ hours.

Estimation of bacterial number in a suspension: At the end of incubation periods, the number of colonies on each plate was counted. Average of the duplicates were taken and the number of colonies were multiplied by the dilution factor and calculated as $1 \mathrm{ml}$ of original sample [25].They were then expressed as colony forming unit per $\mathrm{ml}(\mathrm{cfu} / \mathrm{ml})$ of the sample.

Sensory analysis: Sensory evaluation was carried out on the samples for overall acceptability using 5-point Hedonic scale, where a score of 1 indicated poor sensory attribute and a score of 5 indicated excellent sensory attribute. A panel of 15 judges familiar with tomato-carrot juice were selected and presented with the coded samples. Panelists were instructed to rinse their mouth between samples test to avoid effects of residual flavors [3].

Statistical analysis: Data generated from all the experiments were statistically analyzed using SPSS (Version 13) software and independent $t$ sample test at level of significance $p<0.05$ using LSD and Turkey's test.

\section{Results and Discussion \\ pH and titratable acidity}

Changes in the $\mathrm{pH}$ and titratable acidity of tomato-carrot juice blends with and without hydrocolloids are presented in Table 1. There was no significant difference between the samples with and without hydrocolloid at ambient temperature $(\mathrm{t}=1.04$, $p=0.74)$ and refrigeration temperature ( $\mathrm{t}=1.07, p=0.61$ ) for $\mathrm{pH}$ of the samples. The $\mathrm{pH}$ of the juice decreased for the blend with and without hydrocolloid at ambient temperature and increased at refrigeration temperature with storage time. The $\mathrm{pH}$ of the juice blend with hydrocolloid (4.54) was lower than the $\mathrm{pH}$ of the blend without hydrocolloid (4.62) at ambient 
Table 1: Physico-Chemical Analysis of Tomato-Carrot Juice Blends with/ without Hydrocolloids Stored at Ambient and Refrigeration Temperatures.

\begin{tabular}{|c|c|c|c|c|c|c|c|c|c|c|}
\hline $\begin{array}{l}\text { Timet in } \\
\text { Weeks }\end{array}$ & $\begin{array}{l}\text { Sam- } \\
\text { ple } \\
\text { code }\end{array}$ & pH & $\begin{array}{l}\text { Acidity }(\% \text { cit- } \\
\text { ric acid } / 100 \mathrm{ml})\end{array}$ & $\left({ }^{\circ}\right.$ Brix $)$ & Ash (\%) & Moisture (\%) & $\begin{array}{c}\text { Total } \\
\text { solids } \\
\text { (g/100g) }\end{array}$ & $\begin{array}{l}\text { Viscosity } \\
\text { (m Pa.s) }\end{array}$ & $\begin{array}{l}\text { Reducing } \\
\text { sugar (mg/ } \\
\text { ml) }\end{array}$ & $\begin{array}{c}\text { Vitamin C } \\
\text { (mg A.A } / 100 \mathrm{ml} \text { ) }\end{array}$ \\
\hline \multirow{2}{*}{0} & $\mathrm{Aa}$ & $5.40 \pm 0.01$ & $0.03 \pm 0.00$ & $5.50 \pm 0.01$ & $0.63 \pm 0.04$ & $94.93 \pm 0.50$ & $3.09 \pm 0.09$ & $169.50 \pm 2.59$ & $7.00 \pm 0.01$ & $4.26 \pm 0.07$ \\
\hline & $\mathrm{Ba}$ & $5.32 \pm 0.01$ & $0.17 \pm 0.04$ & $5.30 \pm 0.01$ & $0.53 \pm 0.11$ & $94.33 \pm 0.08$ & $3.47 \pm 0.08$ & $165.80 \pm 2.23$ & $6.00 \pm 0.04$ & $4.15 \pm 0.14$ \\
\hline \multirow{4}{*}{2} & $\mathrm{Aa}$ & $4.73 \pm 0.01$ & $0.07 \pm 0.01$ & $5.20 \pm 0.04$ & $0.63 \pm 0.04$ & $93.53 \pm 0.89$ & $3.20 \pm 0.00$ & $162.10 \pm 3.75$ & $7.00 \pm 0.00$ & $3.27 \pm 0.08$ \\
\hline & $\mathrm{Ba}$ & $4.64 \pm 0.01$ & $0.29 \pm 0.00$ & $5.10 \pm 0.16$ & $0.60 \pm 0.00$ & $94.00 \pm 0.42$ & $3.10 \pm 0.16$ & $156.90 \pm 3.31$ & $8.00 \pm 0.00$ & $3.14 \pm 0.00$ \\
\hline & $\mathrm{Ar}$ & $4.98 \pm 0.01$ & $0.05 \pm 0.01$ & $5.30 \pm 0.08$ & $0.60 \pm 0.04$ & $94.83 \pm 0.37$ & $4.20 \pm 0.37$ & $174.85 \pm 2.61$ & $6.00 \pm 0.03$ & $3.94 \pm 0.00$ \\
\hline & $\mathrm{Br}$ & $4.87 \pm 0.01$ & $0.17 \pm 0.04$ & $5.20 \pm 0.01$ & $0.60 \pm 0.07$ & $95.00 \pm 0.14$ & $3.00 \pm 0.14$ & $160.30 \pm 2.42$ & $10.00 \pm 0.01$ & $3.62 \pm 0.07$ \\
\hline \multirow{4}{*}{4} & $\mathrm{Aa}$ & $5.03 \pm 0.01$ & $0.14 \pm 0.02$ & $5.30 \pm 0.14$ & $0.60 \pm 0.00$ & $94.67 \pm 0.89$ & $3.33 \pm 0.22$ & $144.70 \pm 3.75$ & $5.00 \pm 0.02$ & $2.75 \pm 0.08$ \\
\hline & $\mathrm{Ba}$ & $4.92 \pm 0.01$ & $0.92 \pm 0.07$ & $5.20 \pm 0.00$ & $0.55 \pm 0.11$ & $95.57 \pm 0.42$ & $2.67 \pm 0.12$ & $\begin{array}{c}139.50 \pm \\
2.98\end{array}$ & $10.00 \pm 0.00$ & $2.40 \pm 0.00$ \\
\hline & $\mathrm{Ar}$ & $5.35 \pm 0.01$ & $0.09 \pm 0.00$ & $5.30 \pm 0.00$ & $0.60 \pm 0.07$ & $94.00 \pm 0.37$ & $4.00 \pm 0.00$ & $190.25 \pm 1.77$ & $7.00 \pm 0.03$ & $3.58 \pm 0.07$ \\
\hline & $\mathrm{Br}$ & $5.31 \pm 0.01$ & $0.49 \pm 0.04$ & $5.10 \pm 0.14$ & $0.60 \pm 0.11$ & $94.00 \pm 0.14$ & $4.00 \pm 0.00$ & $\begin{array}{c}154.70 \pm \\
1.95\end{array}$ & $8.00 \pm 0.04$ & $2.68 \pm 0.04$ \\
\hline \multirow{4}{*}{6} & Aa & $4.77 \pm 0.01$ & $0.15 \pm 0.01$ & $5.10 \pm 0.07$ & $0.55 \pm 0.11$ & $95.26 \pm 0.19$ & $4.90 \pm 0.17$ & $148.50 \pm 2.76$ & $3.50 \pm 0.06$ & $2.46 \pm 0.08$ \\
\hline & $\mathrm{Ba}$ & $4.64 \pm 0.01$ & $0.30 \pm 0.02$ & $5.10 \pm 0.11$ & $0.50 \pm 0.00$ & $95.20 \pm 0.42$ & $4.60 \pm 0.19$ & $\begin{array}{c}124.80 \pm \\
1.98\end{array}$ & $12.00 \pm 0.03$ & $2.21 \pm 0.08$ \\
\hline & $\mathrm{Ar}$ & $5.36 \pm 0.01$ & $0.12 \pm 0.00$ & $5.40 \pm 0.08$ & $0.56 \pm 0.04$ & $93.75 \pm 0.37$ & $5.36 \pm 0.17$ & $199.70 \pm 1.77$ & $14.00 \pm 0.01$ & $3.26 \pm 0.04$ \\
\hline & $\mathrm{Br}$ & $5.30 \pm 0.01$ & $0.20 \pm 0.07$ & $5.10 \pm 0.08$ & $0.53 \pm 0.11$ & $93.35 \pm 0.14$ & $4.67 \pm 0.09$ & $147.90 \pm 4.10$ & $12.00 \pm 0.02$ & $2.36 \pm 0.07$ \\
\hline \multirow{4}{*}{8} & $\mathrm{Aa}$ & $4.54 \pm 0.01$ & $0.15 \pm 0.04$ & $5.00 \pm 0.04$ & $0.50 \pm 0.00$ & $95.61 \pm 0.19$ & $3.50 \pm 0.17$ & $166.70 \pm 3.75$ & $3.00 \pm 0.00$ & $2.24 \pm 0.07$ \\
\hline & $\mathrm{Ba}$ & $4.62 \pm 0.01$ & $0.40 \pm 0.07$ & $4.90 \pm 0.07$ & $0.31 \pm 0.01$ & $95.33 \pm 0.42$ & $3.67 \pm 0.07$ & $96.80 \pm 3.12$ & $12.00 \pm 0.07$ & $1.96 \pm 0.08$ \\
\hline & $\mathrm{Ar}$ & $5.37 \pm 0.01$ & $0.06 \pm 0.00$ & $5.20 \pm 0.07$ & $0.31 \pm 0.04$ & $95.92 \pm 0.17$ & $3.10 \pm 0.00$ & $207.40 \pm 2.55$ & $15.00 \pm 0.00$ & $2.96 \pm 0.07$ \\
\hline & $\mathrm{Br}$ & $5.34 \pm 0.01$ & $0.32 \pm 0.07$ & $5.00 \pm 0.04$ & $0.42 \pm 0.03$ & $95.13 \pm 0.28$ & $3.08 \pm 0.06$ & $139.95 \pm 1.95$ & $7.00 \pm 0.02$ & $2.01 \pm 0.04$ \\
\hline
\end{tabular}

$\mathrm{A}=$ Tomato- carrot juice blend with hydrocolloids; $\mathrm{B}=$ Tomato-carrot juice blend without hydrocolloids; $\mathrm{a}=$ ambient temperature; $\mathrm{r}=$ refrigeration temperature.

Table 2: Lycopene, Carotenoid, Conductivity and Level of Sedimentation Analyses of Tomato-Carrot Juice Blends with/ without Hydrocolloids Stored at Ambient and Refrigeration Temperature

\begin{tabular}{|c|c|c|c|c|c|}
\hline $\begin{array}{l}\text { Time in } \\
\text { Weeks }\end{array}$ & Sample code & Carotenoid (mg/100g) & Lycopene (mg/100g) & Conductivity $(\mu S)$ & Level of sedimentation (\%) \\
\hline \multirow{2}{*}{0} & Aa & $3.90 \pm 0.17$ & $4.97 \pm 0.05$ & $5.03 \pm 0.16$ & 96.25 \\
\hline & $\mathrm{Ba}$ & $3.23 \pm 0.12$ & $4.36 \pm 0.06$ & $4.83 \pm 0.04$ & 45.50 \\
\hline \multirow{4}{*}{2} & Aa & $3.28 \pm 0.11$ & $3.60 \pm 0.03$ & $5.10 \pm 0.07$ & 75.40 \\
\hline & $\mathrm{Ba}$ & $2.55 \pm 0.06$ & $4.64 \pm 0.01$ & $5.10 \pm 0.09$ & 40.60 \\
\hline & $\mathrm{Ar}$ & $3.39 \pm 0.05$ & $4.10 \pm 0.05$ & $4.93 \pm 0.04$ & 85.50 \\
\hline & $\mathrm{Br}$ & $2.88 \pm 0.09$ & $4.68 \pm 0.03$ & $4.67 \pm 0.04$ & 43.25 \\
\hline \multirow{4}{*}{4} & $\mathrm{Aa}$ & $2.38 \pm 0.07$ & $3.28 \pm 0.13$ & $5.10 \pm 0.07$ & 58.50 \\
\hline & $\mathrm{Ba}$ & $2.28 \pm 0.29$ & $3.19 \pm 0.05$ & $5.47 \pm 0.08$ & 39.50 \\
\hline & $\mathrm{Ar}$ & $1.47 \pm 0.11$ & $3.83 \pm 0.05$ & $4.90 \pm 0.00$ & 70.50 \\
\hline & $\mathrm{Br}$ & $1.80 \pm 0.11$ & $4.22 \pm 0.07$ & $4.00 \pm 0.07$ & 41.50 \\
\hline \multirow{4}{*}{6} & Aa & $2.33 \pm 0.13$ & $2.68 \pm 0.09$ & $5.40 \pm 0.00$ & 53.20 \\
\hline & $\mathrm{Ba}$ & $2.36 \pm 0.07$ & $3.67 \pm 0.04$ & $5.30 \pm 0.08$ & 33.50 \\
\hline & $\mathrm{Ar}$ & $2.40 \pm 0.19$ & $3.83 \pm 0.01$ & $5.00 \pm 0.07$ & 55.50 \\
\hline & $\mathrm{Br}$ & $2.08 \pm 0.16$ & $4.22 \pm 0.18$ & $4.63 \pm 0.00$ & 38.30 \\
\hline \multirow{4}{*}{8} & Aa & $1.54 \pm 0.01$ & $2.68 \pm 0.09$ & $5.43 \pm 0.00$ & 48.50 \\
\hline & $\mathrm{Ba}$ & $1.52 \pm 0.01$ & $3.67 \pm 0.04$ & $5.00 \pm 0.10$ & 30.00 \\
\hline & $\mathrm{Ar}$ & $1.99 \pm 0.05$ & $3.83 \pm 0.01$ & $5.00 \pm 0.00$ & 50.25 \\
\hline & $\mathrm{Br}$ & $1.42 \pm 0.05$ & $4.22 \pm 0.18$ & $4.60 \pm 0.00$ & 35.50 \\
\hline
\end{tabular}

$\mathrm{A}=$ Tomato- carrot juice blend with hydrocolloids; $\mathrm{B}=$ Tomato-carrot juice blend without hydrocolloids; $\mathrm{a}=$ ambient temperature; $\mathrm{r}=$ refrigeration temperature. 
temperature while the $\mathrm{pH}$ of the blend with hydrocolloid (5.37) was higher than that of the blend without hydrocolloid (5.34) at refrigeration temperature. Xanthan gum solutions are very resistant to $\mathrm{pH}$ variations, i.e. they are stable in both alkaline and acidic conditions and the solutions have excellent stability at low $\mathrm{pH}$ over long time periods [21].The titratable acidity of the blend with and without hydrocolloid increased with storage time at ambient and refrigeration temperatures. There was no significant difference between the samples with and without hydrocolloid at ambient temperature $(\mathrm{t}=1.39, p=0.06)$ and refrigeration temperature $(\mathrm{t}=1.21, p=0.08)$ for titratable acidity of the samples. Samples with hydrocolloid at both temperatures had lower percentage of citric acid.

\section{Degree Brix ( ${ }^{\circ}$ Brix)}

There was no significant difference between the samples stored at ambient temperature $(\mathrm{t}=1.89, p=0.38)$ and at refrigeration temperature between the sample with and without hydrocolloids ( $\mathrm{t}=1.26, p=0.06)$. However, there was reduction in ${ }^{\circ}$ Brix with storage time at both temperatures.

\section{Ash content, moisture content and total solids (g/100g)}

The ash content of both blends was stable at ambient and refrigeration temperatures. There was no significant difference at ambient $(\mathrm{t}=1.15, p=0.17)$ and refrigeration temperature $(\mathrm{t}$ $=1.42, p=0.13$ ). Nielsen [26] reported that hydrocolloids do not have effect on the ash content of juice because they solubilize and therefore may not be detected. The moisture content of both blends was relatively stable at both temperatures, though there was a slight increase for both blends and at both temperatures. There was no significant difference in the moisture content of the samples at ambient temperature $(\mathrm{t}=1.35, p=0.42)$ and refrigeration temperature $(\mathrm{t}=1.57, p=0.31)$. Values obtained for both blends were close at both temperatures. CMC has been reported to have no effect on moisture content [27]. The total solids of both samples were not significantly different at ambient $(\mathrm{t}=1.89, p=0.39)$ and refrigeration temperatures $(\mathrm{t}=1.26, p$ $=0.61$ ). There was an increase in the total solid content of the blends but at the $8^{\text {th }}$ week, there was a decrease.

\section{Viscosity of the fruit juice blends}

There was a significant difference between the viscosity of samples stored at ambient temperature $(\mathrm{t}=2.93, p=0.04)$ and the sample stored at refrigeration temperature $(t=1.71$, $p=0.00$ ). The viscosity of both blends decreased with storage time at ambient temperature. Higher viscosity values were observed for the blend with hydrocolloid (166.70 mPa.s) than for the blends without hydrocolloid ( $96.8 \mathrm{mPa} . \mathrm{s}$ ) by the $8^{\text {th }}$ week. Beristain et al. [28] reported that the presence of hydrocolloids (carboxylmethylcellulose and xanthan gum) increases the viscosity of juice stored at room temperature. At refrigeration temperature, the blend with hydrocolloid increased from 169.5 $\mathrm{mPa}$.s at week 0 to $207.4 \mathrm{mPa}$.s by the $8^{\text {th }}$ week of the storage time, while the blend without hydrocolloid decreased with storage time. Sharma et al. [21] reported that the viscosity of aqueous solution of xanthan is nearly independent of temperature over a wide range. The viscosity of a xanthan solution is virtually unaffected by temperatures from freezing point to boiling point of pure water. Thus the rheological properties (viscosity) of the final products remain stable irrespective of being kept in a refrigerator. The viscosity loss is reversible and upon cooling the original high viscosity is recovered. In addition, the viscosity of CMC solution is inversely related to temperature [29].

\section{Reducing sugar of the fruit juice blends}

The changes in reducing sugar content of the blends with and without hydrocolloid as shown in Table 1 were significant $(\mathrm{t}=$ $3.43, p=0.04$ ) at ambient temperature but showed no significant difference at refrigeration temperature $(t=8.69, p=0.74)$. At ambient storage, reducing sugar content for the blend without hydrocolloid $(12 \mathrm{mg} / \mathrm{ml})$ was more than what was obtained for the blend with hydrocolloid $(3 \mathrm{mg} / \mathrm{ml})$ at the end of 8 weeks of storage. The sugar content of the blend without hydrocolloid increased with storage time while the blend with hydrocolloid decreased with storage time. On the other hand, at refrigeration temperature, the sugar content of the blend with hydrocolloid $(15 \mathrm{mg} / \mathrm{ml})$ was more than that obtained for the blend without hydrocolloid (7 mg/ml). There was a decrease in sugar content with storage for the blend with hydrocolloid and an increase with storage time for blend without hydrocolloid at ambient temperature but the reverse was the case with refrigeration temperature.

\section{Vitamin $\mathrm{C}$ contents of the fruit juice blends}

Table 1 shows the changes in vitamin $\mathrm{C}$ content of tomatocarrot juice blend with and without hydrocolloids stored at ambient and refrigeration temperatures. There was no significant difference between the samples at ambient $(\mathrm{t}=2.09, p=0.69)$ and refrigeration temperature $(\mathrm{t}=3.01, p=0.21)$. The juice blend with hydrocolloid had more vitamin $\mathrm{C}$ content at ambient storage (2.24 mg A.A $/ 100 \mathrm{ml}$ ) and refrigeration temperature $(2.96 \mathrm{mg}$ A.A $/ 100 \mathrm{ml}$ ) than the blend without hydrocolloid (1.96 mg A.A $/ 100 \mathrm{ml}$ and $2.01 \mathrm{mg} \mathrm{A.A} / 100 \mathrm{ml}$ respectively) at the 8 week of storage. There was decrease in the vitamin $C$ content during the period of storage at both temperatures. Hydrocolloids help to prevent oxidation of vitamin $\mathrm{C}$ in beverages and this could have been responsible for the higher values obtained for blends with hydrocolloid [30].

\section{Carotenoid and lycopene contents of the fruit juice blends}

Changes in the carotenoid and lycopene content of juice blend with and without hydrocolloids stored at ambient and refrigeration temperatures are shown in Table 2. There was no significant difference between the samples at ambient $(\mathrm{t}=1.72, p$ $=0.70)$ and refrigeration temperature $(t=4.01, p=0.52)$ for the carotenoid content while the lycopene value was not significant at ambient temperature $(\mathrm{t}=3.09, p=0.56)$ and refrigeration temperature $(\mathrm{t}=1.34, p=0.66)$. The carotenoid and lycopene values were more in the blends with hydrocolloid than in the blends without hydrocolloid at the initial and final week of storage at both temperatures. There was a decrease in the carotenoid and 
lycopene content with storage time at ambient and refrigeration temperatures. Hydrocolloids are to prevent oxidation of carotene in beverages and this could have been responsible for the higher values obtained for blends with hydrocolloid [30]. The main causes of tomato lycopene degradation during processing maybe due to isomerization and oxidation [31]. Isomerization converts all- trans isomers to cis-isomers due to additional energy input and results in an unstable, energy-rich station. Determination of the degree of lycopene isomerization during processing would provide a measure of the potential health benefits of tomato-based foods. Thermal processing (bleaching, retorting, and freezing processes) generally causes some loss of lycopene in tomato-based foods. Heat induces isomerization of the alltrans to cis forms. The cis-isomers increase with temperature and processing time [31]. The principal cause of carotenoid loss during processing and storage of food is enzymatic or nonenzymatic oxidation [32].

\section{Conductivity}

Changes in conductivity and viscosity of tomato-carrot juice blend with and without hydrocolloids stored at ambient and refrigeration temperatures are shown in Table 2. Results showed that there was no significant difference between the samples stored at ambient temperature $(\mathrm{t}=2.38, p=0.62)$ but at refrigeration temperature, there was a significant difference between the sample containing the hydrocolloids and the sample without hydrocolloids $(\mathrm{t}=3.57, p=0.02)$. The conductivity of both blends stored at ambient temperature increased with storage time and decreased at refrigeration temperature. The result agrees with that obtained by Sevugan and Sudhir [33] on the conductivity of tomato juice. However, the values obtained from the blend with hydrocolloid $(5.43,5.0)$ were higher than that without hydrocolloid $(5.0,4.9)$ at both temperatures.

\section{Level of sedimentation}

As shown in Table 2, there was a significant reduction in the level of sedimentation in the sample with hydrocolloid stored at ambient temperature $(\mathrm{t}=6.57, p=0.01)$ and at refrigeration temperature $(\mathrm{t}=8.83, p=0.01)$. The juice with hydrocolloid as shown in Table 2 was able to stabilize settled while the reverse was the case for the juice without hydrocolloid. Nussinovitch [34] reported that the presence of hydrocolloid helps to stabilize juice. Sinchaipanit and Kerr [35] reported that difference in the sedimentation of samples was probably caused by the different velocity of pulp migration to the bottom due to gravitational acceleration, the viscosity of the system and the density difference between the solids and the supporting liquid. The blanching process helps to stabilize cloudiness but did not prevent sedimentation. Shu-chen [36] reported that for improving the cloud stability of G. paraguayens juice, adding hydrocolloids (0.17-0.3\% carboxymethylcellulose; $0.1-0.3 \%$ pectin and $0.05-$ $0.2 \%$ xanthan gum) was efficient. Beristain et al. [28] reported that stability in fruit juice with hydrocolloid was as a result of the association of the free carboxyl groups of the polysaccharides which gives a negative charge with the exposed protein such as the charge repulsion between the protein-polysaccharide complex and the pulp. It was observed that as the viscosity decreases, sedimentation increased as reported by Imeson [29].

\section{Colour measurement}

Addition of hydrocolloid was able to stabilize and enhance colour stability as shown in Table 3. The standard colour measurement for the blend with hydrocolloid was 2.5YR 4.65 / 8.9 while the blend without hydrocolloid was 2.5YR 4.65 / 9.04. Throughout the period of storage, there was no change in the hue value (2.5YR) for both blends and at both storage temperatures. At the $4^{\text {th }}$ week, the Value and Chroma for the blend with hydrocolloid was 4.61/10.16 and 4.65/10.37 for ambient and refrigeration temperature respectively while the blend without hydrocolloid had a value of 4.57 for both temperatures and chroma of 11.29 and 11.14 for ambient and refrigeration temperature, respectively. This indicates that the blend with hydrocolloid retained the colour of the juice better than the blend without hydrocolloid at both temperatures. By the $8^{\text {th }}$ week, the blend with hydrocolloid at ambient temperature was able to retain the colour of the juice better than the other blends (2.5YR 4.25 / 9.69, 2.5YR 3.91 / 9.74 for blend with hydrocolloid and 2.5YR 3.97 / 11.45, 2.5YR

Table 3: Colour Measurement of Tomato-Carrot Juice Blends with / without Hydrocolloids Stored at Ambient and Refrigeration Temperatures.

\begin{tabular}{|c|c|c|c|c|}
\hline Time in Weeks & $\begin{array}{c}\text { Sample } \\
\text { code }\end{array}$ & Hue & Value & Chroma \\
\hline \multirow{2}{*}{0} & $\mathrm{Aa}$ & 2.5YR & 4.65 & 8.9 \\
\hline & $\mathrm{Ba}$ & $2.5 Y R$ & 4.65 & 9.04 \\
\hline \multirow{4}{*}{2} & Aa & $2.5 \mathrm{YR}$ & 4.61 & 8.42 \\
\hline & $\mathrm{Ba}$ & $2.5 \mathrm{YR}$ & 4.57 & 9.14 \\
\hline & $\mathrm{Ar}$ & $2.5 \mathrm{YR}$ & 4.65 & 9.07 \\
\hline & $\mathrm{Br}$ & $2.5 \mathrm{YR}$ & 4.57 & 9.09 \\
\hline \multirow{4}{*}{4} & $\mathrm{Aa}$ & $2.5 \mathrm{YR}$ & 4.61 & 10.16 \\
\hline & $\mathrm{Ba}$ & $2.5 \mathrm{YR}$ & 4.57 & 11.29 \\
\hline & $\mathrm{Ar}$ & $2.5 Y R$ & 4.65 & 10.37 \\
\hline & $\mathrm{Br}$ & $2.5 \mathrm{YR}$ & 4.57 & 11.14 \\
\hline \multirow{4}{*}{6} & Aa & $2.5 \mathrm{YR}$ & 4.25 & 11.4 \\
\hline & $\mathrm{Ba}$ & $2.5 Y R$ & 3.91 & 9.69 \\
\hline & $\mathrm{Ar}$ & $2.5 Y R$ & 4.13 & 10.53 \\
\hline & $\mathrm{Br}$ & $2.5 Y R$ & 4.15 & 10.53 \\
\hline \multirow[t]{4}{*}{8} & Aa & $2.5 Y R$ & 4.25 & 9.69 \\
\hline & $\mathrm{Ba}$ & $2.5 Y R$ & 3.97 & 11.45 \\
\hline & $\mathrm{Ar}$ & $2.5 Y R$ & 3.91 & 9.74 \\
\hline & $\mathrm{Br}$ & $2.5 \mathrm{YR}$ & 0.74 & 10.8 \\
\hline
\end{tabular}

$\mathrm{A}=$ Tomato- carrot juice blend with hydrocolloids; $\mathrm{B}=$ Tomatocarrot juice blend without hydrocolloids; $\mathrm{a}=$ ambient temperature; $\mathrm{r}=$ refrigeration temperature.

Hue - The attribute of colour perception by means of which an object is judge to be red, yellow, green, blue, purple or intermediate.

Chroma - The department of the colour from a gray having the same Munsell value expressed on a scale extending from 0 by steps of approximately equal visual importance to about 20 for the strongestcoloured specimens producible.

Value - The daylight reflectance of a specimen expressed on a scale extending from 0 for ideal black to 10 for ideal white by steps of approximately equal visual importance. 
3.74 / 10.80) for blend without hydrocolloid at ambient and refrigeration temperature respectively. According to Qin et al. [37], the colour and cloud stability of cloudy carrot juice were improved by enzymatic hydrolysis and addition of hydrocolloids. The darker colour obtained in the blends without hydrocolloid could be due to oxidation of ascorbic acid and precipitation of pigments, as hydrocolloid helps in retaining these properties [38]. Qin et al. [37] also reported that change in colour of carrot juice product involves the co-precipitation of colour substances such as $\beta$-carotene with larger molecules or enzymatic and oxidative discolouration.

\section{Effect of hydrocolloids on microbial counts of tomato- carrot juice blend}

The total viable (bacteria) counts of the juice blend are presented in Table 4. There was no significant difference between the samples at ambient temperature $(\mathrm{t}=6.79, p=0.09)$ and refrigeration temperature $(\mathrm{t}=5.25, p=0.61)$. The viable (bacteria) counts also decreased with storage time. The initial bacterial count for the blend with hydrocolloid reduced from $3.53 \log _{10}$ (cfu/ $\mathrm{ml}$ ) to 3.47 and $3.27 \log _{10} \mathrm{cfu} / \mathrm{ml}$ for ambient and refrigeration temperature respectively while the blend without hydrocolloid reduced from $3.57 \log _{10}(\mathrm{cfu} / \mathrm{ml})$ to 3.33 and $2.81 \log _{10} \mathrm{cfu} / \mathrm{ml}$ for ambient and refrigeration temperature respectively by the $8^{\text {th }}$ week for samples. The decrease in the bacteria count could be attributable to the presence of preservative which inhibit microbiological growth and carrot is considered as antibacterial agent against pathogenic micro organisms [39]. This indicates that hydrocolloids did not have significant effect on the bacterial count of the juice blend. It has also been reported by Szilard et al. [40] that pasteurization of freshly prepared carrot juice at $80^{\circ} \mathrm{C}$ for 20 mins decreased the microbial population to below limit - 10 colonies - forming unit ( $\mathrm{cfu} / \mathrm{ml})$. The total yeast and mold count of the juice blend is presented in Table 4 . There was no significant difference between the samples at ambient temperature $(\mathrm{t}=2.72, p=0.87)$ and refrigeration temperature $(\mathrm{t}=$ $2.39, p=0.11$ ). As storage time increased, the population of yeast and mould counts drastically decreased. The yeast and mould count for blend without hydrocolloid were 1.81 and $1.30 \log _{10}$ (sfu/ml) for ambient and refrigeration temperature respectively while the blend without hydrocolloid had 2.04 and $1.65 \log _{10}$ (sfu/ml) for ambient and refrigeration temperature by the end of the $8^{\text {th }}$ week of storage. Lower values were obtained for blends with hydrocolloid and this decrease may also be attributed to the stabilizers possible affecting the growth of the organisms.

\section{Effect of hydrocolloid on the nutritional properties of the juice blend}

The addition of hydrocolloid to the juice blend prevented the loss of nutrients, retained the nutritional composition of the blend and inhibited the growth of micro-organisms as stated above. It has also be reported that hydrocolloids replaces fat which helps to reduce the risk for cardiovascular disease [41].

\section{Sensory analysis}

The blend with hydrocolloid was significantly different
(Table 5a) from the blend without hydrocolloid in taste $(\mathrm{t}=$ 2.87, $p=0.01)$, colour $(\mathrm{t}=3.20, p=0.00)$, level of sedimentation (stability) ( $\mathrm{t}=3.89, p=0.00)$, flavour $(\mathrm{t}=3.18, p=0.00)$ and overall acceptability $(\mathrm{t}=4.09, p=0.00)$ at ambient temperature. At refrigeration temperature (Table $5 b$ ), the blend with hydrocolloid was significantly different from the blend without hydrocolloid in colour $(\mathrm{t}=2.74, p=0.01)$ and overall acceptability $(\mathrm{t}=2.80, p=$ $0.01)$ but there was no significant difference in taste $(\mathrm{t}=1.88, p=$ 0.07 ) and flavour ( $t=0.37, p=0.71)$. The taste of the blends was both acceptable, although, the presence of hydrocolloid did not depressed the taste of the juice blend. It has been reported by Pastor et al. [42], that addition of methylcellulose did not alter the perceived sweetness in aspartame-sweetened peach nectars and xanthan addition, even at $0.10 \%$, significantly lowered sweetness of samples sweetened with the highest aspartame concentration $(0.644 \mathrm{~g} / \mathrm{L})$.

\section{Conclusion}

This study has shown that the addition of hydrocolloid to tomato-carrot juice blend had no significant effect $(\mathrm{t}=1.07, p>$ 0.05 ) in the $\mathrm{pH}$, moisture content, ash content, total solids, vitamin $\mathrm{C}$, carotenoids and lycopene content of tomato-carrotjuice blend at ambient and refrigeration temperature. At ambient temperature, the brix level and conductivity had no significant difference $(\mathrm{t}=1.89, p>0.05)$ but was significantly better at refrigeration temperature $(\mathrm{t}=1.26, p<0.05)$. The titratable acidity, viscosity,

Table 4: Microbial Counts of Tomato-Carrot Juice Blends with/ without Hydrocolloids Stored at Ambient and Refrigeration Temperatures.

\begin{tabular}{|c|c|c|c|}
\hline $\begin{array}{l}\text { Time in } \\
\text { Weeks }\end{array}$ & $\begin{array}{l}\text { Sample } \\
\text { Code }\end{array}$ & $\begin{array}{l}\text { Total viable counts } \\
(\log 10 \mathrm{cfu} / \mathrm{ml})\end{array}$ & $\begin{array}{l}\text { Yeast and mold counts } \\
(\log 10 \mathrm{sfu} / \mathrm{ml})\end{array}$ \\
\hline \multirow{2}{*}{0} & Aa & $3.53 \pm 0.19$ & $2.59 \pm 0.07$ \\
\hline & $\mathrm{Ba}$ & $3.57 \pm 0.04$ & $2.68 \pm 0.02$ \\
\hline \multirow{4}{*}{2} & Aa & $3.67 \pm 0.09$ & $2.37 \pm 0.03$ \\
\hline & $\mathrm{Ba}$ & $3.41 \pm 0.10$ & $2.49 \pm 0.01$ \\
\hline & $\mathrm{Ar}$ & $3.50 \pm 0.01$ & $2.20 \pm 0.05$ \\
\hline & $\mathrm{Br}$ & $3.49 \pm 0.08$ & $1.89 \pm 0.03$ \\
\hline \multirow{4}{*}{4} & Aa & $3.52 \pm 0.07$ & $2.36 \pm 0.13$ \\
\hline & $\mathrm{Ba}$ & $3.02 \pm 0.23$ & $2.46 \pm 0.05$ \\
\hline & $\mathrm{Ar}$ & $3.40 \pm 0.14$ & $2.39 \pm 0.05$ \\
\hline & $\mathrm{Br}$ & $3.41 \pm 0.11$ & $1.50 \pm 0.07$ \\
\hline \multirow{4}{*}{6} & $\mathrm{Aa}$ & $3.49 \pm 0.08$ & $2.23 \pm 0.09$ \\
\hline & $\mathrm{Ba}$ & $3.30 \pm 0.22$ & $2.30 \pm 0.04$ \\
\hline & $\mathrm{Ar}$ & $3.33 \pm 0.19$ & $2.20 \pm 0.01$ \\
\hline & $\mathrm{Br}$ & $3.40 \pm 0.14$ & $1.65 \pm 0.18$ \\
\hline \multirow{4}{*}{8} & Aa & $3.47 \pm 0.11$ & $2.04 \pm 0.00$ \\
\hline & $\mathrm{Ba}$ & $3.33 \pm 0.01$ & $1.81 \pm 0.07$ \\
\hline & $\mathrm{Ar}$ & $3.27 \pm 0.05$ & $1.65 \pm 0.21$ \\
\hline & $\mathrm{Br}$ & $2.81 \pm 0.15$ & $1.30 \pm 0.00$ \\
\hline
\end{tabular}

$\mathrm{A}=$ Tomato- carrot juice blend with hydrocolloids; $\mathrm{B}=$ Tomatocarrot juice blend without hydrocolloids; $\mathrm{a}=$ ambient temperature, $\mathrm{r}=$ refrigeration temperature. 
Table 5a: Independent Samples Test Samples with / without Hydrocolloid at Ambient Temperature.

\begin{tabular}{|c|c|c|c|c|c|c|c|c|c|c|}
\hline & & \multicolumn{2}{|c|}{$\begin{array}{c}\text { Levene's Test } \\
\text { for Equality of } \\
\text { Variances }\end{array}$} & \multicolumn{5}{|c|}{ t-test for Equality of Means } & \multicolumn{2}{|c|}{$\begin{array}{l}\text { 95\% Confidence } \\
\text { Interval of } \\
\text { the Difference }\end{array}$} \\
\hline & & $\mathbf{F}$ & Sig. & $\mathbf{t}$ & df & $\begin{array}{c}\text { Sig. } \\
\text { (2-tailed) }\end{array}$ & $\begin{array}{c}\text { Mean } \\
\text { Difference }\end{array}$ & $\begin{array}{l}\text { Std. Error } \\
\text { Difference }\end{array}$ & Lower & Upper \\
\hline \multirow[b]{2}{*}{ Taste } & Equal variances assumed & 0.925 & 0.344 & 2.872 & 28 & 0.008 & 1.00000 & 0.34824 & 0.28667 & 1.71333 \\
\hline & $\begin{array}{l}\text { Equal variances not } \\
\text { assumed }\end{array}$ & & & 2.872 & 27.828 & 0.008 & 1.00000 & 0.34824 & 0.28647 & 1.71353 \\
\hline \multirow[b]{2}{*}{ color } & Equal variances assumed & 0.652 & 0.426 & 3.199 & 28 & 0.003 & 1.26667 & 0.39601 & 0.45547 & 2.07786 \\
\hline & $\begin{array}{l}\text { Equal variances not } \\
\text { assumed }\end{array}$ & & & 3.199 & 27.978 & 0.003 & 1.26667 & 0.39601 & 0.45544 & 2.07789 \\
\hline \multirow{2}{*}{$\begin{array}{l}\text { sedimenta- } \\
\text { tion }\end{array}$} & Equal variances assumed & 0.571 & 0.456 & 3.891 & 28 & 0.001 & 1.66667 & 0.42836 & 0.78921 & 2.54412 \\
\hline & $\begin{array}{c}\text { Equal variances not } \\
\text { assumed }\end{array}$ & & & 3.891 & 27.021 & 0.001 & 1.66667 & 0.42836 & 0.78778 & 2.54556 \\
\hline \multirow[b]{2}{*}{ flavor } & Equal variances assumed & 2.549 & 0.122 & 3.182 & 28 & 0.004 & 1.20000 & 0.37712 & 0.42750 & 1.97250 \\
\hline & $\begin{array}{l}\text { Equal variances not } \\
\text { assumed }\end{array}$ & & & 3.182 & 24.108 & 0.004 & 1.20000 & 0.37712 & 0.42184 & 1.97816 \\
\hline \multirow[t]{2}{*}{$\begin{array}{l}\text { Overall } \\
\text { accept }\end{array}$} & Equal variances assumed & 0.134 & 0.717 & 4.085 & 28 & 0.000 & 1.40000 & 0.34272 & 0.69796 & 2.10204 \\
\hline & $\begin{array}{l}\text { Equal variances not } \\
\text { assumed }\end{array}$ & & & 4.085 & 27.934 & 0.000 & 1.40000 & 0.34272 & 0.69789 & 2.10211 \\
\hline
\end{tabular}

Table 5b: Independent Samples Test Samples with / without Hydrocolloid at Refrigeration Temperature.

\begin{tabular}{|c|c|c|c|c|c|c|c|c|c|c|}
\hline & & \multicolumn{2}{|c|}{$\begin{array}{l}\text { Levene's Test } \\
\text { for Equality of } \\
\text { Variances }\end{array}$} & \multicolumn{5}{|c|}{ t-test for Equality of Means } & \multicolumn{2}{|c|}{$\begin{array}{l}\text { 95\% Confidence } \\
\text { Interval of } \\
\text { the Difference }\end{array}$} \\
\hline & & $\mathbf{F}$ & Sig. & $\mathbf{t}$ & df & $\begin{array}{c}\text { Sig. } \\
\text { (2-tailed) }\end{array}$ & $\begin{array}{c}\text { Mean } \\
\text { Difference }\end{array}$ & $\begin{array}{l}\text { Std. Error } \\
\text { Difference }\end{array}$ & Lower & Upper \\
\hline \multirow[b]{2}{*}{ Taste } & Equal variances assumed & 0.949 & 0.338 & 1.876 & 28 & 0.071 & 0.66667 & 0.35546 & -0.06145 & 1.39479 \\
\hline & $\begin{array}{l}\text { Equal variances not } \\
\text { assumed }\end{array}$ & & & 1.876 & 26.013 & 0.072 & 0.66667 & 0.35546 & -0.06397 & 1.39730 \\
\hline \multirow[b]{2}{*}{ color } & Equal variances assumed & 0.062 & 0.806 & 2.743 & 28 & 0.011 & 0.80000 & 0.29168 & 0.20251 & 1.39749 \\
\hline & $\begin{array}{l}\text { Equal variances not } \\
\text { assumed }\end{array}$ & & & 2.743 & 26.664 & 0.011 & 0.80000 & 0.29168 & 0.20116 & 1.39884 \\
\hline \multirow{2}{*}{$\begin{array}{l}\text { sedimenta- } \\
\text { tion }\end{array}$} & Equal variances assumed & 5.742 & 0.023 & 0.957 & 28 & 0.347 & 0.40000 & 0.41786 & -0.45594 & 1.25594 \\
\hline & $\begin{array}{l}\text { Equal variances not } \\
\text { assumed }\end{array}$ & & & 0.957 & 24.788 & 0.348 & 0.40000 & 0.41786 & -0.46096 & 1.26096 \\
\hline \multirow[b]{2}{*}{ flavor } & Equal variances assumed & 0.497 & 0.487 & 0.367 & 28 & 0.716 & 0.13333 & 0.36341 & -0.61107 & 0.87774 \\
\hline & $\begin{array}{l}\text { Equal variances not } \\
\text { assumed }\end{array}$ & & & 0.367 & 27.502 & 0.717 & 0.13333 & 0.36341 & -0.61168 & 0.87834 \\
\hline \multirow{2}{*}{$\begin{array}{l}\text { Overall } \\
\text { accept }\end{array}$} & Equal variances assumed & 0.572 & 0.456 & 2.800 & 28 & 0.009 & 0.93333 & 0.33333 & 0.25053 & 1.61614 \\
\hline & $\begin{array}{l}\text { Equal variances not } \\
\text { assumed }\end{array}$ & & & 2.800 & 27.252 & 0.009 & 0.93333 & 0.33333 & 0.24969 & 1.61698 \\
\hline
\end{tabular}

level of sedimentation of the juice blend with hydrocolloid also showed significant difference $(\mathrm{t}=3.39, p<0.05)$ at both temperatures. But the blend with hydrocolloids was able to retain the juice quality better than the blend without hydrocolloid. The microbial result revealed that there was no significant difference in yeast and mold count at both temperatures $(t=2.72, p>0.05)$ while the total viable (bacteria) count was significantly different $(\mathrm{t}=6.70, p<0.05)$ at ambient temperature but had no significant effect at refrigeration temperature $(\mathrm{t}=5.25, p>0.05)$. There was a better colour retention on the juice with hydrocolloids than on the juice without hydrocolloid while the sensory results showed that addition of hydrocolloid increased the acceptability of the juice blend $(\mathrm{t}=1.24, p<0.05)$ in colour, level of sedimentation and overall acceptability. Product with hydrocolloid was preferred.

\section{References}

1. FAO. Principles and Practices of small and medium scale fruit juice processing. FAO Agricultural Services Bulletin 146. 2000.

2. Office of Dietary Supplements. 2000.

3. Ihekoronye A.I. and Ngoddy PO. Integrated Food Science and Technology for the Tropics. Macmillan publishers, London. 1985; pp 73,306 . 
4. Matsuoka T and Jha S N. Non-destructive determination of acid-brix ratio of tomato juice using near infrared spectroscopy. International Journal of Food Science and Technology. 2004; 39(4): 425-430. DOI: $10.1111 / \mathrm{j} .1365-2621.2004 .00800 . \mathrm{x}$.

5. Rao A.V. Lycopene, Tomatoes, and the Prevention of Coronary Heart Disease. Experimental Biology and Medicine. 2002; 227: 908-913.

6. Harish K.S, Jasmeet K, Bhavesh C.S, Charanjv S. Bahadur S. Effect of pre-treatment conditions on physicochemical parameters of carrot juice. International Journal of Food Science and Technology. 2009; 44: 1-9. DOI: 10.1111/j.1365-2621.2006.01462.x.

7. Rodriguez-Amaya D.B. Carotenoids and Food Preparation: The Retention of Provitamin A Carotenoids in Prepared, Processed, and Stored Foods. John Snow, Inc/OMNI Project, Campinas, SP, Brazil. 1997; pp 2, 7.

8. Nelson PE, Tressler DK. (Eds). Fruits and Vegetables Juice Processing Technology.3rd edition AVI Publishing Co. 1980; pp 268-309.

9. Martin L. Hydrocolloid recipe collection Oslo. 2007; pp 29.

10. Durand A, Franks GV , Hosken R.W. Particle sizes and stability of UHT bovine, cereal and grain milks. Food Hydrocolloids. 2003; pp: 671678(8).

11. Kawakami K, Okabe Y, Norisoye T. 'Dissociation of Dimerized Xanthan In aqueous solution' Carbohydr. Polym. 1990; 14: 189-203. doi:10.1016/0144-8617(90)90030-V.

12. Harding N. E, IelpI L, Cleary J M. 'Genetics and biochemistry xanthan gum production by Xanthomonas campestris' in Food Biotechnology Microorganisms, eds Y. H. Hui and G. C. Khachatourians. VCH Publishers, New York. 1999; pp. 495-514.

13. Mothé, C.E.and Correia, D.Z. (2003). Rheological Properties Of Cashew/Xanthan Gums Blends In Cashew Juice. 3rd International Symposium on Food Rheology and Structure, pp 491-492.

14. Sharma B, Dhuldhoya N.C, Merchant U.C. Carboxymethyl cellulose (CMC) forming a gel. Journal of Polymers and the Environment. 2006; 14: (2), pp 195-202.

15. Genovese D. B, Lozano J E. Effect of cloud particle characteristics on the viscosity of cloudy apple juice. Journal of Food Science. 2000; 65(4), 641-645. DOI: 10.1111/j.1365-2621.2000.tb16065.x.

16. Alakali J S, Okonkwo T M, Iordye E M. Effect of stabilizers on the physico-chemical and sensory attributes of thermized yogurt. African Journal of Biotechnology. 2008; 7 (2):158-163. DOI: 10.5897/ AJB08.543.

17. Arash K, Amir G, Seyed M A, Seyed A M, Todor V. The rheological properties of ketchup as a function of different hydrocolloids and temperature. International Journal of Food Science and Technology. 2008; 44(3): 596-602. DOI: 10.1111/j.1365-2621.2008.01868.x.

18. A.O.A.C. (2000).Official methods of analysis of the Association of Official Analytical Chemists, 17 th ed. AOAC International, Gaithersburg, MD.

19. Abiose, S.H. and Adedeji, A.A. (1994). Biochemical changes during fermentation of plantain. Nigerian Food Journal, 12:92-99.

20. Sadler G, Davis J, Dezman D. Rapid extraction of lycopene and $\beta$-carotene from reconstituted tomato paste and pink grapefruit homogenate. Journal of food Science. 1990; 55(5): 1460-1. DOI: 10.1111/j.1365-2621.1990.tb03958.x

21. Sharma SK, Le Maguer M. Kinetics of lycopene degradation in tomato pulp solids under different processing and storage conditions. Food
Research International. 1996; 29(3-4): 309-315. doi:10.1016/09639969(96)00029-4.

22. Davies BH. Carotenoids. In: Goodwin TW, editor. Chemistry and Biochemistry of Plant Pigments. Academic Press: London; 1976.

23. Sahin S, Sumnu SG. Physical Properties of Foods. Springer Science \& Business Media: New York; 2006.

24. Ogbulie JN, Uwazuoke JC, Oghiehor SI. Introductory Microbiology Practical. Springfield publishers: Nigeria: 1998.

25. Olutiola PO, Famurewa O, Sonntag HG. An Introduction to General Microbiology: A Practical Approach. Pub Heidelberg, Germany: 1991.

26. Nielsen SS. Chemical Analysis of Foods. Kluwer Academic/Plenum Publishers: Netherlands; 2003.

27. Linberg JS. Quantitation of Dialysis: Historical Perspective. Serminars in Dialysis. 2001; 14(4): 238-245.

28. Beristain CI, Sosa FC, Lobato-Calleros C, Pedroza-Islas R, Rodriguez ME, Verde-Calvo JR. Applications of soluble dietary fibers in beverages. Revista Mexicana de Ingenieria Quimica. 2006; 5(1): 81-95.

29. Imeson A. Thickening and gelling agents for food. 2nd edn. Blackie Academic and Professional: London; 1997.

30. Gavrilov AS. Industrial Production of Lycopene by a Microbiological Method. Applied Chemistry and Microbiology. 1996; 32 (5): 492-494.

31. Shi J, Le Maguer M. Lycopene in Tomatoes: Chemical and Physical Properties Affected by Food Processing. Crit Rev Biotechnol. 2000; 20(4): 293-334.

32. Rodriguez-Amayal DB, Rodriguez EB, Amaya-Farfan J. Advances in Food Carotenoid Research: Chemical and Technological Aspects, Implications in Human Health. Malaysian Journal of Nutrition. 2006; 12 (1):101-121.

33. Sevugan P, Sudhir KS. Electrical Conductivity of elected Juices: Influences of Temperature, Solids content, Applied voltage and Particle size. Food \& Nutrition Press Inc: USA; 1991.

34. Nussinovitch A. Hydrocolloid Applications: Gum Technology in the Food and other Industries. Chapman and Hall: Great Britain; 1997.

35. Sinchaipanit P, Kerr WL. Effect of Reducing Pulp-Particles on the Physical Properties of Carrot Juice. ASEAN Food Journal. 2007; 14 (3): 205-214.

36. Shu-chen Y. Effect of hydrocolloid compositions of Graptopetalum paraguayens and food gums on cloud stability of G. paraguayens juice. 2006; MSc thesis, China.

37. Qin L, Xu S, Zhang W. Effect of enzymatic hydrolysis on the yield of cloudy carrot juice and the effects of hydrocolloids on colour and cloud stability during ambient storage. Journal of Science of Food And Agriculture. 2005; 85:505-512.

38. Delcio S, Jose BP, Antonio C, June F, Marcio T, Patricia B. Hunter colour dimensions, sugar content, and volatile compounds in pasteurized yellow passion fruit juice (Passiflora edulis var flavicarpa) during storage. Brazilian Archives of Biology and Technology. 2004; 47(2):233-245. Doi: 10.1590/S1516-89132004000200011.

39. Salwa AA, Galal EA, Neimat EA. Carrot Yoghurt : Sensory, Chemical, Microbiological Properties and Consumer Acceptance. Pakistan Journal of Nutrition. 2004; 3(6): 322-330.

40.Szilard K, Judith MR, Quang DN, Agoston H. Changes of microbial population and some components in carrot juice during fermentation 
with selected Bifidobacterium strains. Process Biochemistry. 2008; 43(8): 816-821. doi:10.1016/j.procbio.2008.03.008.

41. Khayrul A, Maruf A, Sorifa A, Nurul I, Jong-Bang E. Effect of Carboxymethylcellulose and Starch as Thickening Agents on the Quality of Tomato Ketchup. Pakistan Journal of Nutrition. 2009; 8(8):
1144-1149. DOI: 10.3923/pjn.2009.1144.1149.

42. Pastor MV, Costell E, Duran L. Effects of Hydrocolloids and aspartame on sensory, viscosity and sweetness of low calorie peach nectars. Journal of Texture Studies. 2007; 27(1): 61-79. DOI: 10.1111/j.17454603.1996.tb00060.x. 